\title{
Historical Discoveries on Viruses in the Environment and Their Impact on Public Health
}

\author{
Thomas Labadie ${ }^{a, b} \quad$ Christophe Batéjat $^{a} \quad$ India Leclercq ${ }^{a, c}$ \\ Jean-Claude Manuguerra ${ }^{a}$ \\ aUnité Environnement et Risques Infectieux, Institut Pasteur, Cellule d'Intervention Biologique d'Urgence (CIBU), \\ Paris, France; bentre de Biochimie Structurale (CBS), UMR 5048, University of Montpellier, CNRS, Montpellier, \\ France; ' Université de Paris, Cellule Pasteur, Paris, France
}

\section{Keywords}

Environmental persistence · Virology · Airborne virus .

Waterborne virus $\cdot$ Public health history

\section{Abstract}

Background: Transmission of many viruses occurs by direct transmission during a close contact between two hosts, or by an indirect transmission through the environment. Several and often interconnected factors, both abiotic and biotic, determine the persistence of these viruses released in the environment, which can last from a few seconds to several years. Moreover, viruses in the environment are able to travel short to very long distances, especially in the air or in water. Summary: Although well described now, the role of these environments as intermediaries or as reservoirs in virus transmission has been extensively studied and debated in the last century. The majority of these discoveries, such as the pioneer work on bacteria transmission, the progressive discoveries of viruses, as well as the persistence of the influenza virus in the air varying along with droplet sizes, or the role of water in the transmission of poliovirus, have contributed to the improvement of public health. Recent outbreaks of human coronavirus, influenza virus, and Ebola virus have also demonstrated the contemporaneity of these research studies and the need to study virus persistence in the environment. Key Messages: In this review, we discuss historical discoveries that contributed to describe biotic and abiotic factors determining viral persistence in the environment.

(c) 2020 S. Karger AG, Basel

\section{Introduction}

Viruses are the most abundant biological entities on earth with $10^{31}$ virions [1]. Viral particles are found everywhere, in the wildness and in urban area, on different surfaces, in biological fluids, and in the air, with temperatures ranging from below $0^{\circ} \mathrm{C}$ to above $30^{\circ} \mathrm{C}[2,3]$. In seawaters, it has been observed that viral particles are present at a higher density compared with bacteria $[4,5]$. This great diversity of environment enables the diversification of transmission modes between individuals among a population. Although the transmission of a virus usually depends on the combination of different factors, such as the contact between the virus and a naive host and the replication capacity of this virus in the naive host, the transmission of a virus secreted in the environment also karger@karger.com www.karger.com/int

(C) 2020 S. Karger AG, Base

Karger"
India Leclercq

Unité Environnement et Risques Infectieux, Institut Pasteur Cellule d'Intervention Biologique d'Urgence (CIBU) 25, Rue du Dr. Roux, FR-75724 Paris (France)

india.leclercq@pasteur.fr 
relies on its survival outside its host [6, 7]. Abiotic factors such as temperature, humidity, $\mathrm{pH}$, water salinity, or the presence of ultraviolet (UV) light are all driving viral transmission by altering or promoting viral particle persistence in the environment. These abiotic factors can cause a more or less significant bottleneck for virus diversity during transmission, depending on the transmission route, as observed with influenza viruses $[8,9]$, or on the seasonal variations, as observed with algal viruses [10].

In the past centuries, scientists studying viruses in the environment made major discoveries for the field of infectious diseases. Their results contributed to understanding the sources of infection as well as pathogen transmissions between infected hosts, leading to an evolution of public health policies. This review presents the history of environmental virology, from a period before virus discovery, where the environment was not considered as a vector until our contemporary era, where the use of modern techniques unveiled new questions on the role played by the environment in virus transmission [11].

\section{Early Discoveries on the Role of the Environment as Reservoir}

In the ancient times, Persian physicians such as $\mathrm{Mu}-$ hammad ibn Zakariya al-Razi (Rhazes) in the 9th century and Ibn Sina (Avicenna) in the 10th century developed pioneer theories on infectious diseases, in which the origins of diseases such as variola, measles, and tuberculosis are external agents present in the contaminated air or water $[12,13]$ (Table 1). Later, Sayyid Ismail Jorjani would even recommend boiling or filtering water before consumption [13, 14]. In 1546, three centuries before the germ theory was admitted and the miasma theory was consequently buried, the Italian physician Girolamo Fracastoro wrote the book De contagione et contagiosis morbis. In this book, he defined the contagion as the transmission of an invisible agent, which could be direct by contact, indirect by fomites, or to a distance $[15,16]$. Although the theory of G. Fracastoro was controversial at this time, his ideas remained influential on the later conception of epidemics and played a role in the response against following tuberculosis outbreaks [17]. However, he assumed that this agent was a chemical substance, rather than a living microorganism [18]. Two centuries later, during Pontiac's war of 1763, the British army contrived to spread smallpox disease on Delaware Indians, using infected blankets [19]. Although this is a famous example in the history of biological warfare, it is not clear if the trial was successful. However, this event illustrates that the possibility of smallpox virus transmission by contact with an infected surface was accepted.

In the 17th century, Antonie van Leeuwenhoek improved the microscopy by creating $>300$ microscopes and cutting-edge lenses made by himself. Thanks to this technical revolution, the nascent microbiology became a more established science, moving forward to observation and experimentation. The awareness of the environment as a reservoir for microorganisms probably really started with Louis Pasteur in 1861 and his germ theory [20] and the German hygienist Carl Flügge, who demonstrated that droplets containing Mycobacterium tuberculosis bacilli, the causative agent of tuberculosis, could remain in the air for several hours [21]. Since then, it is acknowledged that the air is filled with microscopic germs. Even if viruses were not yet discovered and only bacteria were observable, this major discovery allowed developing new techniques for asepsis and sterilization. In the 2 nd half of the 19th century, Joseph Lister developed the sterilization of surgery instruments with phenol and Charles Chamberland invented the autoclave.

At the beginning of the 20th century, new infectious agents called filterable agents were discovered based on their ability to pass through an earthenware filter that retains bacteria, also invented by C. Chamberland [22]. The 1st filterable agent discovered was the tobacco mosaic virus by D. Iwanowski, although M.W. Beijerinck was the 1st to propose that this agent was a virus 6 years later, in 1898 [23]. The same year, Loeffler and Frosch [24] discovered the foot-and-mouth disease virus. During the following 20 years, more than 40 viruses were discovered, including the yellow fever virus, rabies virus, dengue virus, variola virus, poliovirus, and measles virus [25]. In 1918, Charles Nicolle and René Dujarric de la Rivière both simultaneously demonstrated the filterable nature of the agent of influenza, although their results were largely unnoticed $[26,27]$. The influenza virus was eventually isolated again 13 years later [28]. During this period of new discoveries, one-third of all deaths registered in the USA were due to 3 leading causes: pneumonia, tuberculosis, and diarrhoea/enteritis $[29,30]$. In addition, the pandemic influenza A virus of 1918 was responsible for the highest annual mortality rates of the 20th century, causing at least 40 million deaths worldwide [31]. Except for tuberculosis, whose etiologic agent is a bacterium, respiratory and enteric viruses were thus responsible for a large number of deaths. The transmission modes of these viruses involve a step outside their host, and necessarily their spreading efficiency is dependent on their ability to 
Table 1. Early discoveries on pathogen transmission and persistence in the environment

\begin{tabular}{|c|c|c|c|c|}
\hline Period & Discovery & Pathogen/disease & Authors & Ref \\
\hline $9-11$ th centuries & $\begin{array}{l}\text { Infection is caused by an external agent present } \\
\text { in contaminated air/water }\end{array}$ & $\begin{array}{l}\text { Measles, variola, and } \\
\text { tuberculosis }\end{array}$ & $\begin{array}{l}\text { Muhammad ibn Zakariya al-Razi; } \\
\text { ibn Sina; Sayyid Ismail Jorjani }\end{array}$ & {$[12-14]$} \\
\hline 1546 & $\begin{array}{l}\text { Pathogens are invisible and transmitted by direct } \\
\text { contact or indirect by fomites }\end{array}$ & Measles, plague, and typhus & Girolamo Fracastoro & {$[15,16]$} \\
\hline 17 th century & Improvement of the microscopes & - & Antonie van Leeuwenhoek & - \\
\hline 1861 & The germ theory & - & Louis Pasteur & {$[20]$} \\
\hline 1897 & $\begin{array}{l}\text { M. tuberculosis remains in the air for several } \\
\text { hours within droplets }\end{array}$ & M. tuberculosis & Carl Flügge & {$[21]$} \\
\hline 19th century & Sterilization of surgery instruments with phenol & - & Joseph Lister & - \\
\hline 1884 & Invention of the autoclave & - & Charles Chamberland & {$[22]$} \\
\hline $1892-1898$ & Discovery of viruses & $\begin{array}{l}\text { Tobacco mosaic virus and } \\
\text { foot-and-mouth disease virus }\end{array}$ & $\begin{array}{l}\text { D. Iwanowski; M.W. Beijerinck; F. } \\
\text { Loeffler; P. Frosch }\end{array}$ & {$[23,24]$} \\
\hline 1930 & $\begin{array}{l}\text { Provided experimental evidence of airborne virus } \\
\text { transmission }\end{array}$ & Influenza virus & William Firth Wells & {$[36,37]$} \\
\hline 1943 & $\begin{array}{l}\text { Demonstrated that the humidity regulates virus } \\
\text { persistence in aerosols }\end{array}$ & Influenza virus & C.G. Loosli et al. & {$[45]$} \\
\hline 1943 & Evidence of waterborne virus transmission & $\begin{array}{l}\text { Poliovirus and hepatitis } A \\
\text { virus }\end{array}$ & $\begin{array}{l}\text { J. Rhodes et al.; S.G. Lensen et al.; } \\
\text { J.R. Paul et al.; J.R. Neefe et al. }\end{array}$ & $\begin{array}{l}{[55} \\
61-63]\end{array}$ \\
\hline 1979 & $\begin{array}{l}\text { Water as natural medium for the spread of virus } \\
\text { among wild birds }\end{array}$ & Influenza virus & $\begin{array}{l}\text { Virginia S. Hinshaw, Robert G. } \\
\text { Webster, and Bruce Turner }\end{array}$ & {$[78]$} \\
\hline
\end{tabular}

persist in the environment. Unfortunately, the lack of knowledge at the beginning of the century regarding the transmission of these viruses prevented an efficient response from the public health services, contributing to their high prevalence rate.

During this period, scientists gradually found evidence of the influence of environmental abiotic factors on virus survival. In 1900, F.W. Elgin [32] demonstrated that the vaccine virus could be preserved at low temperature and wrote, "It has always been the popular assumption that germ life was incompatible with extreme cold and that in fact most germs [...] were destroyed by a freezing temperature." In this article, he concluded, "Points are unreliable when stored for any length of time at any temperature" and "Hot and especially variable temperatures speedily injure vaccine." It opened the door to many studies describing virus survival in a wide array of different environments. For example, in 1915, after discovering an immune substance against the poliovirus (the serum treatment) in experimentally infected monkeys [33], Simon Flexner assessed the poliovirus survival contained in a central nervous organ from rhesus macaque in anaero-

History of Discoveries on Virus Persistence in the Environment bic condition at $37^{\circ} \mathrm{C}$ [34]. In this study, he inoculated monkeys by intracerebral injection of brain fragments at different time points and concluded that the survival period of the virus in these conditions was between 20 and 30 days.

Despite the evident progression made at this time in the public health area, the full role of the environment in the transmission of viruses was still underestimated. A complete overview of the knowledge during this period comes from Charles V. Chapin, now considered as a pioneer in public health research. In 1910, he published a book to estimate the relative importance of different factors involved in the transmission of infectious diseases [35]. C.V. Chapin wrote in introduction, "We know now that direct contact with the sick, or with healthy carriers of disease germs, is an exceedingly frequent mode of transmission and that infection by means of the air, or from infected articles, is not nearly as common as was formerly believed." According to him, the transmission mode of pathogens by direct contact is "the most obvious," whereas the transmissions by fomites, air, food, and drink are very much less important. Nonetheless, his de- 
scriptions of the transmission modes mostly reflected the scientific knowledge at this period, mainly focussed on bacteria. Although his writings have been important in the public health history, the scientific concepts in this book have been challenged in the next decades, as more viruses were progressively discovered.

\section{History of Research on Environmental Transmissions: From Basic Knowledge to Public Health Application}

\section{Environmental Transmission through the Air}

To the best of our knowledge, the oldest experimentation published on airborne transmission of viruses came from the 1930s, with the work of the American scientist William Firth Wells [36]. He established that bioaerosols created by sneezing or coughing carry both viruses and bacteria. Moreover, he developed an air centrifuge [37] to demonstrate that the droplet falling velocity depends on droplet mass, which tends to decrease over the distance due to the evaporation. Indeed, the smallest droplets evaporate faster than they fall and can stay in the air for hours or days (Fig. 1a). These observations have led him to make a distinction between droplets and droplet nuclei, and he postulated that different airborne transmission routes exist depending on the droplet size. This theory is now widely accepted. Wells and Brown [38] performed their 1st demonstrations with bacteria, but soon moved to experiments with influenza virus in 1936, 5 years after the confirmation that the etiologic agent of influenza was a virus $[28,39]$. Wells atomized a liquid suspension of influenza virus into a closed tank under irradiation or not with UV light. He then removed a known volume of air at different intervals and collected the suspended material from the air tank to the Wells air centrifuge that he developed himself. He then inoculated ferrets to assess the presence of viable influenza viruses in the collected materials. In conclusion, he observed that ferrets became sick when inoculated with influenza virus previously suspended in the air for $30 \mathrm{~min}$ in absence of UV light. On the other hand, ferrets were not sick when viral particles in the air had a prior exposure to UV irradiation. The bactericidal effect of UV was already known at that time, but this experiment was the 1st demonstration that UV also had a virucidal effect.

After this finding, Wells et al. [40] launched in 1937 a 5 -year epidemiological trial in different schools, with the purpose of studying the effect of air disinfection with UV lights on the prevalence of mumps, chickenpox, and mea- sles among pupils. UV lights were installed in classrooms, as well as in the music room, the library, the nature room, the hall, the lunchroom, the rest room, and the gymnasium, which were thus all irradiated (Fig. 1b). As a control, several classrooms were kept non-irradiated. Measles, chickenpox, and mumps cases were also recorded among school children for 5 or 9 years prior to the UV light installation in the different schools. Wells et al. [40] noticed an important decrease in mumps, chickenpox, and measles cases during the trial, with no epidemic spread among pupils from the irradiated classrooms, whereas epidemic spread occurred among pupils from the non-irradiated classrooms. As a most significant result, he observed that during the year 1941, 14.5, 15.7, and $9 \%$ of susceptible pupils from different schools were infected with measles in irradiated rooms, whereas 55.3 and $51.8 \%$ of cases among pupils were recorded in non-irradiated rooms. He concluded that "epidemic contagion is spread through the medium of confined atmospheres and can be prevented by radiant disinfection of air." After that, similar epidemiological studies were also performed in hospitals, with similar results obtained [41]. Similarly, a recent study performed in an elementary school in the USA reported that influenza virus genome was detectable in aerosols $\left(10^{1}-10^{4}\right.$ genome copies $/ \mathrm{m}^{3}$ air $)$ sampled at different locations during the influenza season [42], suggesting that the air is an important vector for virus transmission in schools.

The environmental persistence of viruses has always been studied both in the field and in the laboratory, allowing us to study the environment as a whole or each variable individually. In order to study experimental airborne infections, different systems were developed. In 1940, Wells [43] published a system composed of an atomizer, a chamber where animals were exposed to infected air, and an incinerator providing airflow in addition to the compressed air bottle and incinerating the effluent air from the animal chamber. In 1943, an English scientist, Derrick G.F. Edward et al. [44], argued that "the use of UV radiation for disinfecting air appears likely in future to become of considerable practical importance." His purpose was to complete the previous epidemiological studies on virus inactivation in the presence of UV with more quantitative results obtained in a laboratory. He designed a set up in which he atomized viral suspension of influenza virus, herpes virus, or vaccinia virus into a cylinder irradiated by using a UV lamp. An irradiation time of $6 \mathrm{~s}$ for influenza virus particles and $1 \mathrm{~s}$ for herpes virus and vaccinia virus particles was necessary for inactivating these viruses and decontaminating the air. Gradually, lab- 
Fig. 1. Early studies on virus persistence in the air. a In 1934, Wells [36] published this figure, presenting his results from an experiment assessing the time required for liquid droplets varying in size to fall on the ground, or to evaporate, after being released $2 \mathrm{~m}$ above the ground. According to his results, which were obtained in a saturated air, liquid droplets having a diameter a little smaller than $0.15 \mathrm{~mm}$ will evaporate before reaching the ground. $\mathrm{He}$ also deduced from this data that in the same atmosphere, a droplet of a diameter of 1-10 $\mu \mathrm{m}$ could stay in the air between $10 \mathrm{~min}$ and 16 h. Later, W.F. Wells carried on this work by studying the persistence of virus contained in small droplets and deduced that aerosols are a major vector of airborne pathogens. b In 1942, Wells et al. [40] published the results of an epidemiological survey in schools, where he tested the effect of the presence of ultraviolet radiation on the epidemics of varicella, measles, and mumps. This photography of a classroom from the Germantown Friends School is presented in his study.

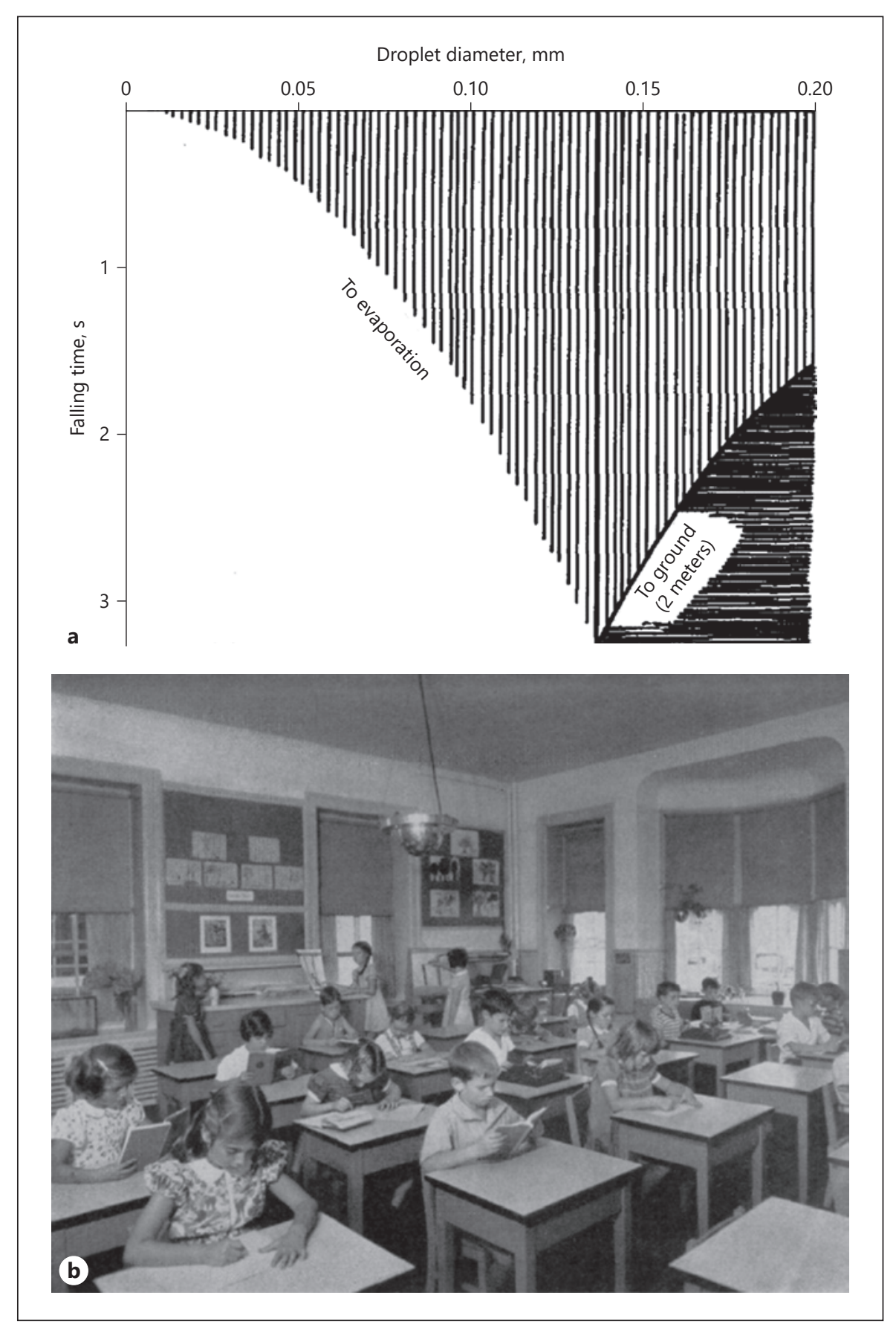

oratory technologies became more complex and research started to focus on the climatic factors driving airborne infection. To this regard, studies performed on the influenza virus were pioneered. In 1943, using a room of 800 cubic feet capacity ( 23 cubic metres) with controlled temperature and humidity, Loosli et al. [45] demonstrated that influenza virus particles persisted longer in aerosols when the atmosphere had a low level of relative humidity. In their experiments, they sprayed a virus suspension in an atmosphere with a high relative humidity $(80-90 \%)$ at $27-29^{\circ} \mathrm{C}$ and observed that the aerosols were no longer infective $1 \mathrm{~h}$ after spraying, by placing mice in the chamber to test whether they became infected. In an atmosphere with $45-55 \%$ relative humidity, aerosolized par- 
Fig. 2. Experimental chamber for the study of airborne infection. a In 1946, Robertson et al. [46] developed a chamber for studying the impact of temperature and humidity on the aerosol transmission of viruses and bacteria. An atomizer was placed in the chamber to spray a bacterial or viral suspension, with an airflow generated by a fan. b The schematic plan shows the atmospheric control system, which could control the relative humidity from 12 to $95 \%$ and the temperature from 10 to $37^{\circ} \mathrm{C}$ in the chamber. The relative humidity was increased by the production of steam, and the air temperature was controlled by orienting the airflow in either a heating chamber or a cooling chamber before being released in the main chamber.

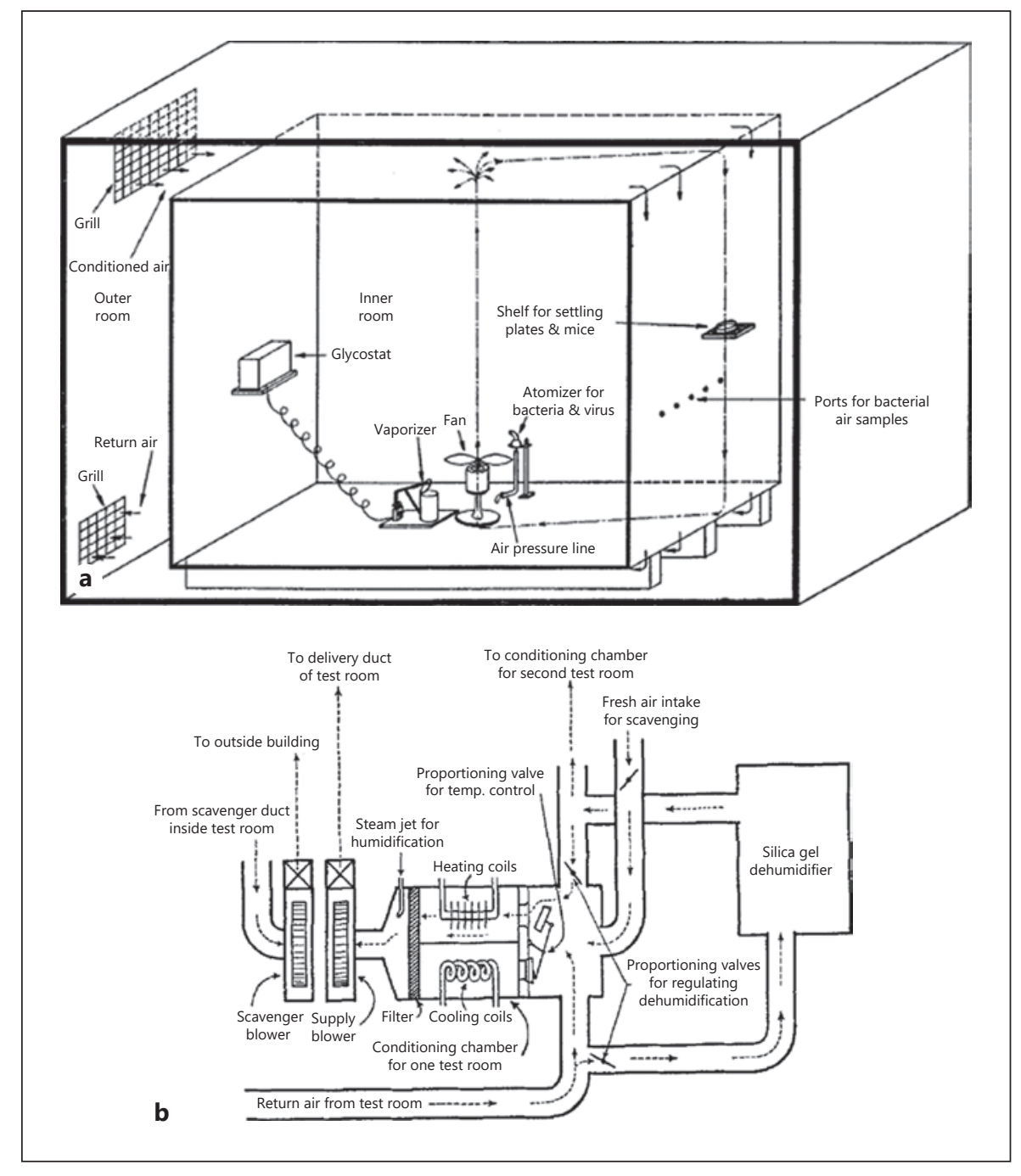

ticles remained infective for $6 \mathrm{~h}$. Finally, in a low-humidity (17-24\%) atmosphere, viral particles remained infectious for at least $24 \mathrm{~h}$. In 1946, Robertson et al. [46] described the construction of 2 similar chambers of 640 cubic feet capacity for experimental airborne infections (Fig. 2b). By controlling the atmosphere in the room, they observed that the infectivity of influenza virus in the air decreased around $50 \%$ relative humidity at $22-23^{\circ} \mathrm{C}$, but was kept maximal below $40 \%$ relative humidity and above $70 \%$ [47], which was partially contradictory with the study by Loosli et al. [45]. In this study, they were also able to increase the virus persistence in a 50\% relative humidity atmosphere, by dialyzing the viral suspension prior to its aerosolization in order to separate the salts from the viral particles. They concluded, "The deleterious influence of humidity was related to the presence of sodium chloride in the atomized suspension." Similar results on the effect of humidity were obtained 60 years later with guinea pigs instead of mice [7]. In this more recent work using guinea pigs, Lowen et al. [7] studied the effect of temperature along with relative humidity on influenza virus persistence in the air and concluded that cold and dry conditions favour transmission. In 1968, Mitchell et al. [48] observed that among 14 strains of influenza A viruses, the 6 stains of "human origin were more susceptible to decay than the 8 strains of avian origin" when aerosolized. For this study, the authors used a rotating drum [49], designed to allow a longer persistence of aerosols in suspension, in which temperature and humidity were controlled. Simultaneously, studies were performed to describe the persistence of influenza viruses on various surfaces [50]. Edward et al. [44] reported an uncommon 
experiment in 1941, where they shook a virus-impregnated blanket and then successfully isolated infectious virus particles distributed in the air after shaking. They also analyzed the virus infectivity after drying on serge, sheet, dust, and glass slides under different temperatures and found that virus particles persisted more on the glass slides. More recently, it has been confirmed that the porosity of a surface negatively affects the persistence of a virus $[51,52]$.

\section{Environmental Transmission through Water}

The poliovirus, which is the causative agent of poliomyelitis, was 1st isolated from the human faeces in 1912 by Swedish scientists $[53,54]$. However, in the beginning of the 1940s, poliomyelitis had never been associated with poor drinking water supplies and this virus had not yet been isolated from contaminated waters [55]. In 1943, Maxcy et al. [56] concluded that from the epidemiological point of view, poliomyelitis does not behave like a waterborne disease. They argued that no outbreaks of widely scattered cases were observed in cities with municipal water supplies and that cities with water sources located in remote spots far from human habitation suffered from poliomyelitis as frequently compared with cities that obtained their water from polluted streams [56-58]. Despite different studies showing that the poliovirus was very resistant and remained viable for weeks in stools and water [58-60], the role of water in virus transmission was ignored until the 1940s. This can also be explained partly because the poliovirus was considered as a neurotropic virus only, based on the symptoms caused among patients. Following the development of virus concentration methods, a higher sensitivity of virus detection methods, and more studies performed on the poliovirus survival in water $[55,61]$ and in sewages $[60,62]$, as well as the discovery of other waterborne viruses, such as the hepatitis A virus [63], the poliovirus was finally recognized as a waterborne virus. Moreover, Sabin and Ward [64] detected the poliovirus in the human digestive tract in 1941 and demonstrated that it is the primary entry site for poliovirus infection.

Simultaneously, abiotic factors driving virus particles' stability in water were identified, such as the water salinity on influenza virus persistence [65] or the level of oxygen in water [66] that could have a negative impact on virus particles by increasing the oxidation of the viral capsid. Environment-oriented studies were also performed on the hepatitis A virus, in order to develop new disinfection methods of drinking water by comparing the effect of water filtration and the use of different chlorine con-

History of Discoveries on Virus

Persistence in the Environment centrations [67]. From this period, discoveries in environmental virology and applications in health policy increased over the years. In 1983, Gerald Berg wrote in the introduction of his book, Viral Pollution of the Environment, "20 years ago, there were no data showing that there were any viruses present in London's river water, whereas it is now known that every surface water in the Thames Water Authority region which has been examined for viruses has provided a positive result in routine test. To move from a state of total ignorance of contamination to the acceptance of a virtually $100 \%$ incidence in less than two decades can have few precedents, and we are faced with a growing list of problems in consequence" [68]. In the 1980s, there was a raising awareness of the virus spread through polluted waters among scientists and public health authorities. Water recreational activities, shellfish harvesting and consumption, drinking water supply, crop irrigation, and aerosolization became diverse sources for a potential virus outbreak $[68,69]$.

Consequently, several environmental parameters were studied to better understand the persistence of enteroviruses or rotaviruses in water such as the effect of solar radiation, $\mathrm{pH}$, inorganic ions, temperature, water origin (estuarine or marine), and the presence of sludge or biological factors such as protective bacteria [70-72]. All these studies showed that virus survival in the environment was dependent on multiple parameters that are interconnected (Fig. 3). Overall, the temperature was considered as the most important parameter for predicting rhinovirus and poliovirus persistence in water $[73,74]$. Moreover, it was observed that rhinovirus, influenza virus, or Newcastle disease virus can lose their infectivity after heating treatment without loss of immunogenicity $[75,76]$. In the case of picornaviruses, viral proteins were more rapidly impaired than the viral genome at high temperature, whereas viral genome alteration occurred more rapidly at low temperature [73, 77] (Fig. 3 [78-82]).

Altogether, research studies performed during this period allowed to realize that waterborne viruses can be spread over a long distance in water without a significant loss of infection. In 1979, Hinshaw et al. [83] argued that wild ducks could be the natural reservoir of influenza virus and that water may be a natural medium for the spread of virus among wild birds. To prove it, they isolated infectious virus particles from non-concentrated waters sampled in Alberta lakes. They observed that virus particles remained infectious for 4 days at $22^{\circ} \mathrm{C}$ and for $>30$ days at $0^{\circ} \mathrm{C}$. During the same decade, it was also observed that waterborne viruses were more stable in aquatic medium when associated with solid particles [84-87].

Intervirology 2020;63:17-32

DOI: $10.1159 / 000511575$ 
Fig. 3. Multiple factors affecting viral persistence in the environment. a After being efficiently replicated and released from an infected host, viruses such as airborne or waterborne viruses can be transmitted to a new naïve host by direct transmission through a close contact, or released in the environment, before encountering a new host. b Several factors then determine the persistence of this virus in the environment before a complete loss of infectivity. Among them, the temperature plays a central role in driving environmental persistence. In the air, the temperature affects the relative humidity, which will then modulate the evaporation and thus the size of aerosols. When human respiratory aerosols evaporate, their salinity and $\mathrm{pH}$ vary. The mucins enriched in sialic acid and present in these aerosols have a protective role for influenza virus particles [78, 79]. The presence of sludge in water may also provide a protective effect, with the clay adsorbing polio virus particles and protecting them against ultraviolet radiations [70], although it has a negative effect on the rotavirus resistance to heat treatments [71]. In addition to environmental factors, viral factors are also determinants for virion stability in the environment, such as the presence of mutations in the structural proteins [80,81], or the lipid composition for enveloped viruses [82]. The study of these factors affecting virus persistence contributed greatly to the development of virus control methods and public health in the population, which are summarized in the grey circle.

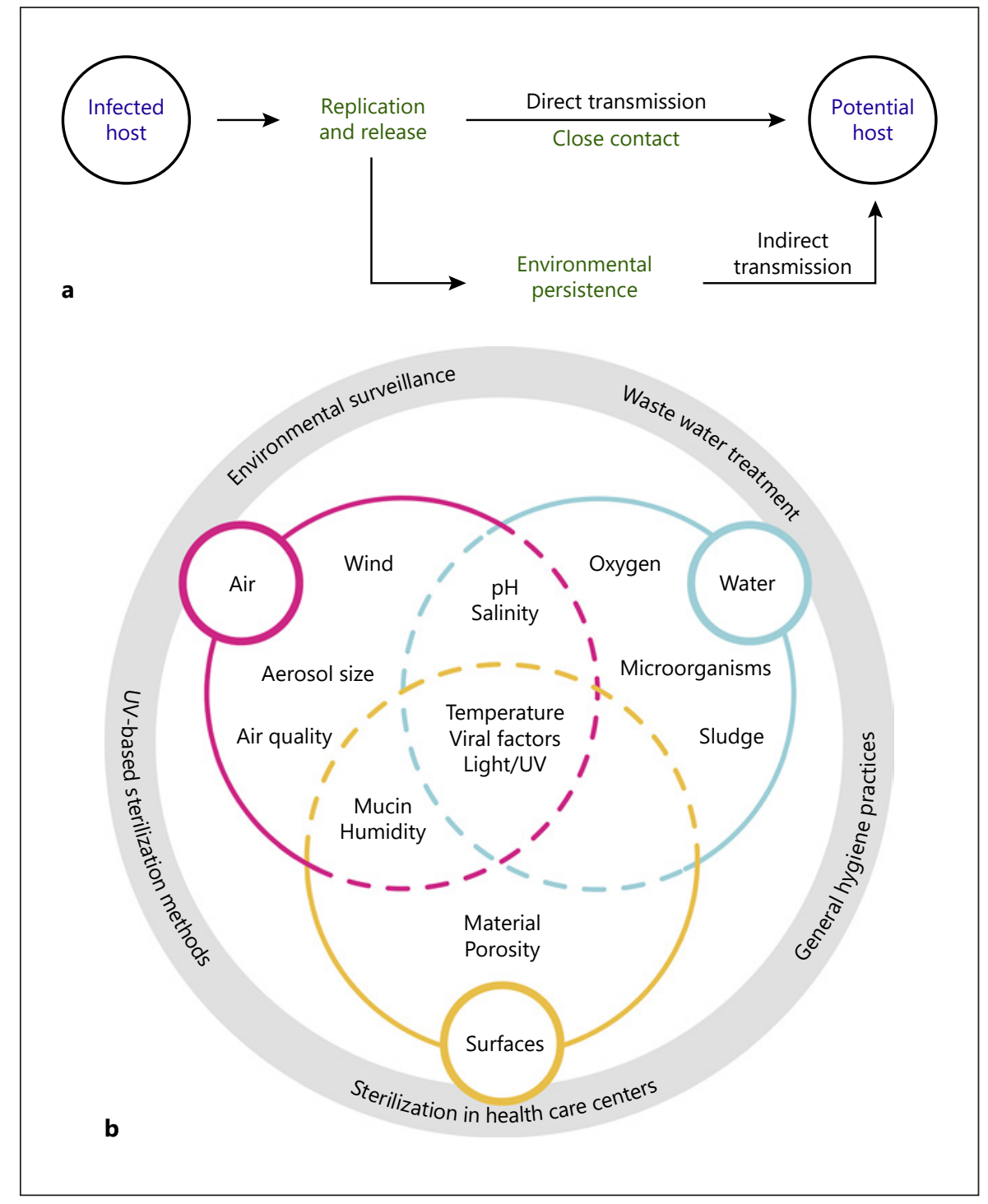

The field of environmental virology allowed to improve water sanitation and public health policies $[57,69]$, leading to more rigorous standards and laws in the USA related to safe drinking water $[69,88]$. Different disinfection methods such as ozonation [89] and chlorine dioxide [90] were developed as alternative to chlorination used for many years $[61,91,92]$ but responsible for the production of suspected carcinogenic compounds in water and used in higher concentration than necessary to be effective. Ozone and chlorine dioxide were already used in Europe at that time [68], and ozone is still a reference for drinking water production. In addition, new antiviral factors, still not completely defined nowadays, have been found in marine water [93-95]. These factors appeared to be thermolabile and sometimes not filterable, guiding suspicions on algae and bacteria [96]. The bacteria Vibrio marinus was later identified as one of these factors. Indeed, it was shown that a lytic suspension of this bacteria added in water was able to inactivate RNA and DNA viruses (poliovirus, adenovirus, influenza virus, echovirus, and Escherichia coli phage T1) at a similar rate than the raw sea water naturally carrying this bacteria $[93,97,98]$. Since then, much research has been performed to describe the mechanisms of viral persistence in the environment. Comprehensive reviews on the latest results on virus persistence and detection methodology have been recently published [74, 99]. 


\section{Viruses in the Environment: Evolution of Concepts}

Concepts in the history of environmental virology evolved as more viruses were discovered and as new technologies and detection methods were developed, such as the improvement of microscopes, centrifugation, and other virus concentration procedures. Epidemiological field studies and laboratory research works led to a considerable improvement in disease surveillance and sanitation during the 20th century. In 1980, Bitton [88] wrote in the preface of his book, Introduction to Environmental Virology, "Environmental virology is now a discipline in its own right." He claimed, "The last decades have witnessed a significant change in outlook and methodology in the field of environmental virology." Nowadays, studying viruses in the environment remained of importance to describe the ecology and transmission of viruses [74]. The recent development of metagenomic approaches brought an unprecedented advantage, by allowing description of viral communities, the virome, in different ecosystems without preconceived knowledge on their composition. Such approach also brings new challenges, due to the amount of viral sequences obtained from the environment, compared with the limited information they provide regarding biological aspects, such as the host or the transmission modes of these viruses [100]. Nevertheless, viral metagenomic studies have been successfully performed on the air [101-103], freshwater and marine waters [104-107], irrigation water [108], in the desert [109], or on surfaces of the Boston and Barcelona subways $[110,111]$. These approaches notably raised new questions on virus carriage by the environment. For example, a marine virus was found in the Namib Desert, leading to the assumption of a virus transportation through the seasonal fog to this area [109]. In-depth analyses of environmental abiotic factors driving the local diversity of viral population, performed in the soil [112] or in waters [113] in different oceans [107], illustrated how environmental factors affect host diversity and thus the viral diversity. For example, a recent ecological and computational study on the influenza virus suggested that variations of environmental persistence between different virus subtypes drive their transmission and thus the viral genetic diversity among aquatic birds [114]. Recently, several works on virus egress from infected cells have described a new mode of virus release, in which multiple viral particles are contained in extracellular vesicles [115], derived either from multivesicular bodies or secretory autophagosomes. This mode of transmission, which allows transmission of several particles in individual cells, has

History of Discoveries on Virus Persistence in the Environment been observed for several non-enveloped viruses with an environmental transmission such as poliovirus [116], rotaviruses, noroviruses [117], and hepatitis A and hepatitis E viruses [118]. It was also demonstrated that these vesicles are very stable in a low-pH environment, as well as in urine, blood, and stools, and thus it is likely that these vesicles increase virus persistence in the environment compared to naked viruses. Moreover, a recent study from Leblanc et al. [119] showed that these enteric viruses have different viral decay patterns on surfaces, in water, and on fruits, with noroviruses presenting a lower stability than the rotaviruses and hepatitis A viruses in these media, raising questions on the molecular determinants explaining these differences.

In addition to the studies of virus in the environment, there is still a significant work focussing on disinfection methods. In particular, a 2-year survey showed that enteroviruses, reoviruses, and adenoviruses remained infectious after a UV treatment in wastewater treatment plants [120]. New UV-based methods were also recently proposed, such as the use of a far-UVC light, which is effective on influenza aerosols without the carcinogenic effects of traditional UV lights on the human skin [121]. Similarly, Nishisaka-Nonaka et al. [122] suggested that UV inactivates the influenza virus by preventing the viral replication without altering the function of the external viral proteins. Interestingly, our previous results showed that after virus inactivation in an aquatic environment, the virus remained able to attach to its cellular receptor, but cannot enter into the cell [80], and presented an unaltered genome $[82,123]$. A new visible-light-induced photocatalyst has also been reported for its virucidal effect on influenza virus, allowing degradation of $99 \%$ of viral particles in $<30$ min with a very weak light source [124]. Another approach has been proposed recently for decontaminating surfaces, such as the use of potassium persulfate, which was effective on Newcastle disease virus and influenza virus [125].

\section{Importance of Virus Persistence Studies in the Light of Recent Epidemics}

Research on virus stability in the environment has also been propelled to the forefront in investigation after recent major outbreaks. In 2003, a non-identified respiratory virus, the severe acute respiratory syndrome-related coronavirus (SARS coronavirus), caused a worldwide outbreak. During the epidemic, numerous transmission events occurred in hospitals, eventually leading to quar- 
antine of the staff and patients in one of these hospitals. Various investigations tried to unveil the transmission of this virus and the potential role played by the environment. Experimental research measured the stability of 2 animal coronaviruses (infecting mice and swine), as a surrogate for the SARS coronavirus, on hard non-porous surfaces [126]. They observed that viruses remained infectious for days at ambient temperature in a wide range of relative humidity $(20-60 \%)$ and that at $40^{\circ} \mathrm{C}$, a low relative humidity (20\%) favoured a longer persistence on surfaces $(>120 \mathrm{~h})$ compared with a high atmospheric humidity. Another study was later performed directly with the SARS coronavirus and gave similar results [127]. However, in a study using mathematical models to question the possibility of long-range airborne transmission during the largest hospital outbreak in Hong Kong, the authors concluded that fomites alone are less likely to explain the transmission chain and that long-range airborne transmission was likely involved [128]. Nine years after the SARS coronavirus, the Middle East respiratory syndrome coronavirus (MERS coronavirus) emerged, causing major outbreaks in Middle Eastern countries, with $>2,400$ cases in the world to date. Because of the wide range of climates in which this virus has been detected, its stability in aerosol was recently explored in different atmospheres [129]. At $25^{\circ} \mathrm{C}$ and $79 \%$ relative humidity, $63 \%$ of the MERS coronavirus remained infectious $1 \mathrm{~h}$ after its aerosolization, whereas at $38^{\circ} \mathrm{C}$ and $24 \%$ relative humidity, reproducing outdoor conditions from the middle-eastern region, only $4.7 \%$ of the virus particles remained infectious after their aerosolization. Very recently, the stability of SARS-CoV-2, the causative agent of the COVID-19 pandemic, was assessed on different surfaces and in aerosols [130]. In this study, the authors report that the SARS-CoV-2 was as persistent as the 2003 SARS coronavirus in aerosols and on surfaces, but more stable on cardboard. In a recent meta-analysis, Kampf et al. [131] reviewed the available information on coronavirus persistence on surfaces and efficient disinfection measures, such as $70 \%$ ethanol and hydrogen peroxide. Similar to the influenza virus, a debate exists on the transmission modes of this virus, with strong arguments in favour of a transmission by expelled droplets and aerosols [132]. In 2013, an unprecedented Ebola virus outbreak started in West African countries. Before this outbreak, it was already known that the Ebola virus could remain stable for several weeks on surfaces and $>1 \mathrm{~h}$ in aerosols under diverse conditions of temperature and humidity $[133,134]$. The transmission of the Ebola virus among humans occurs primarily through direct contact with contaminated fluids [135]. Because of this, a sampling investigation was carried out on various surfaces from 3 Ebola treatment centres in Sierra Leone in order to evaluate the efficiency of the decontamination protocols used by healthcare workers [136]. Because of safety conditions, the presence of the virus was only determined by detecting the viral genome. Positive samples were mainly obtained in the immediate environment of the patients, showing that the decontamination protocols used were effective. A high number of transmission events during this epidemic occurred through close contacts with human corpses during mourning and funeral practices. To assess the infectivity over time of corpseassociated virus, macaques were used in laboratory experiments as a surrogate for human bodies. The authors observed that the Ebola virus remained infectious $>7$ days on the surface of bodies [137].

Despite the research on the influenza particles in aerosols started $>80$ years ago, the relative importance of the different transmission modes of influenza virus among humans, either airborne or by direct and indirect contacts, is still debated $[3,138]$, especially in the case of tropical countries where transmission by fomites may dominate [139]. Recently, progress was made on the design of experimental chambers for studying airborne transmission, with animal cages separated by a particle separator module preventing large droplet transmission between the animals [140]. Similarly, Zhou et al. [141] studied the influence of the diameter of influenza virus-laden aerosols exhaled from infected ferrets into the air on virus transmission. They observed that the influenza virus was mainly transmitted through aerosols having a diameter higher than $1.5 \mu \mathrm{m}$ and suggested for the 1st time that size variations of virus-laden aerosols could exist between different virus strains. The climate is also a factor shaping the physicochemical characteristics of evaporating droplets carrying influenza virus. In fact, when relative humidity decreases, the droplet morphology changes, a phase separation is induced by the loss of water, and the $\mathrm{pH}$ decreases while the droplet salinity increases [142]. Another study, using the bacteriophage Phi 6 as a surrogate for enveloped virus, evaluated how the relative humidity, the absolute humidity, and the temperature affect the virus in droplets [143]. This study showed that the Phi 6 virus survived longer at high (above $85 \%$ ) and low (below $60 \%$ ) relative humidity, leading to the conclusion that this factor was the most important parameter for predicting virus survival. Noticeably, the relative humidity is function of both the temperature and the absolute humidity. The relative humidity in the air is the ratio of partial pres- 


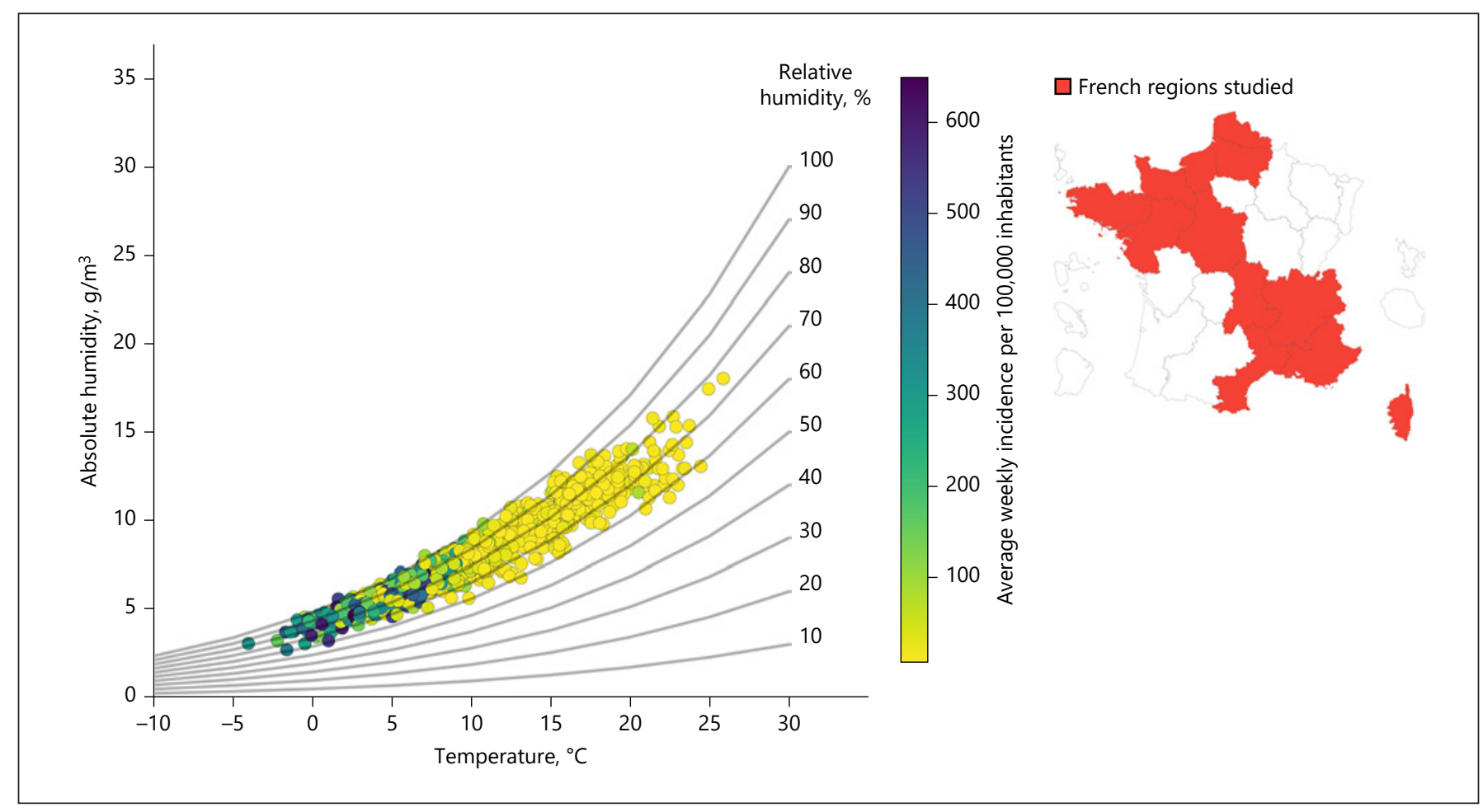

Fig. 4. Average climatic conditions (absolute humidity and temperature) associated with influenza virus reporting in 10 regions of France. The scatter plot shows the average climatic conditions (absolute humidity in $\mathrm{g} / \mathrm{m}^{3}$ and temperature in ${ }^{\circ} \mathrm{C}$ ) of weeks with more than 5 influenza virus (IFV) cases per 100,000 inhabitants reported between 2016 and 2018 in different regions of France (Auvergne-Rhône-Alpes, Bretagne, Centre-Val de Loire, Corse, Hauts-de-France, Normandie, Nouvelle-Aquitaine, Occitanie, Pays de la Loire, and Provence-Alpes-Côte d'Azur). Each point

sure of water to the equilibrium vapour pressure, which equilibrium varies greatly with the temperature. In contrast, the absolute humidity is the actual mass of water vapour in the air, in $\mathrm{g} / \mathrm{m}^{3}$, irrespective of the temperature. As mentioned earlier, most experiments testing the influence of humidity on virus transmission considered only the relative humidity [7, 45-47]. However, recent reports highlighted that absolute humidity is a more likely accurate parameter for predicting influenza virus stability $[144,145]$. While the debate is not completely closed $[146,147]$, it is likely that both parameters are equally valid in countries with a pronounced seasonality of epidemics, as most influenza virus cases arise in winter where the temperature is low, and therefore changes in relative humidity do not reflect important changes in the absolute humidity (Fig. 4). As pointed out by Marr et al. [147], it is also possible that the relative humidity might be a bet- represents a week with $>5$ laboratories confirmed influenza virus cases, and colours reflect incidence per 100,000 inhabitants. The black lines represent the variation of temperature and absolute humidity necessary to maintain specific relative humidity values (10$100 \%)$ in the air. Data of influenza virus incidence reported at the regional level originate from the Réseau Sentinelles (https://www. sentiweb.fr) [151], and climate data originate from the MeteoNet dataset (Meteo France) [152]. ter predicting parameter of influenza transmission in indoor environments, where most transmissions likely happen, and correlate well with the outdoor absolute humidity. A recent attention has also been drawn to the influence of the air pollutants on influenza transmission [148]. It is interesting to note that the role of body fluids in the persistence of influenza virus gained a recent interest, as it was discovered that the mucus has a protective effect on the virus stability when dropped on banknotes [78]. It has also been reported that the mucus also plays a role in maintaining influenza virus infectivity when swallowed in the gastrointestinal tract [149] and in aerosols [150] (Fig. 4 [151, 152]).

Finally, regarding the molecular aspects influencing virus stability in the environment, we and others showed that influenza virus most external proteins, the haemagglutinin and the neuraminidase, are the main driv- 
ers of the environmental persistence of the virus [80, 153-155]. This could potentially explain how different strains of influenza virus or strains from different origins can have different persistence in the environment $[82,156]$. It would be interesting to see if all enveloped viruses that have a class I membrane fusion protein and are transmitted through the environment, such as the coronaviruses or the Ebola virus, could follow the same principle.

\section{Conclusion}

In human history, several scientists understood early the link between the environment and the transmission of infectious disease. They understood that boiling water or avoiding close contacts and confined areas were efficient to prevent the spread of an infection, before the discovery of microorganisms. Since the discovery of the 1st virus a little more than a century ago, many more progresses were accomplished, describing the factors and mechanisms of virus persistence in water, in the air, or on surfaces. Here, we provide a comprehensive review on those historical discoveries that contributed to improve our strategy of virus control. Many more studies will be necessary in the future to describe in details the role of virus persistence in the environment in the virus epidemiology and ecology, or the relative importance of transmission by direct contact in comparison to airborne and waterborne transmission. Of particular interest, it will be essential to predict the impact of the climate change on the transmission of viruses and to observe how viruses adapt to their changing environment.

\section{Acknowledgements}

We express our gratitude to the library of the Institut Pasteur in Paris for their help and support in accessing historical documents. We also wish to acknowledge the help provided by Pr. Maxime Schwartz (National Academy of Sciences) for the references he kindly provided.

\section{Statement of Ethics}

Ethical approval was not required for this project, as it is a synthesis of the scientific literature that did not involve research on human or animal subjects.

\section{Conflict of Interest Statement}

Prof. Jean-Claude Manuguerra is the editor-in-chief of Intervirology, Dr. Thomas Labadie serves as the managing editor, and Prof. India Leclercq is an editor of Intervirology. Mr. Christophe Batéjat has no conflicts of interest to disclose.

\section{Funding Sources}

The authors have no funding source to declare.

\section{Author Contributions}

T.L., C.B., I.L., and J.C. wrote and reviewed the manuscript.

\section{Data Availability Statement}

Data files and notebook used for data analysis of Figure 4 are available on the data repository Figshare (doi: 10.6084/m9.figshare.12672962)

\section{References}

1 Breitbart M, Rohwer F. Here a virus, there a virus, everywhere the same virus? Trends $\mathrm{Mi}$ crobiol. 2005 jun;13(6):278-84.

2 Mäkinen TM, Juvonen R, Jokelainen J, Harju TH, Peitso A, Bloigu A, et al. Cold temperature and low humidity are associated with increased occurrence of respiratory tract infections. Respir Med. 2009 Mar;103(3):456-62.

3 Lowen AC, Steel J, Mubareka S, Palese P. High temperature $\left(30^{\circ} \mathrm{C}\right)$ blocks aerosol but not contact transmission of influenza virus. J Virol. 2008 Jan;82(11):5650-2.

4 Suttle CA. Marine viruses: major players in the global ecosystem. Nat Rev Microbiol. 2007 Oct;5(10):801-12.
5 Angly FE, Felts B, Breitbart M, Salamon P, Edwards RA, Carlson C, et al. The marine viromes of four oceanic regions. PLoS Biol. 2006 Nov; 4(11):e368.

6 Herfst S, Böhringer M, Karo B, Lawrence P, Lewis NS, Mina MJ, et al. Drivers of airborne human-to-human pathogen transmission. Curr Opin Virol. 2017 Feb;22:22-9.

7 Lowen AC, Mubareka S, Steel J, Palese P. Influenza virus transmission is dependent on relative humidity and temperature. PLoS Pathog. 2007 Oct;3(10):1470-6.
8 Varble A, Albrecht RA, Backes S, Crumiller M, Bouvier NM, Sachs D, et al. Influenza A virus transmission bottlenecks are defined by infection route and recipient host. Cell Host Microbe. 2014 Nov;16(5):691-700.

9 Frise R, Bradley K, van Doremalen N, Galiano M, Elderfield RA, Stilwell P, et al. Contact transmission of influenza virus between ferrets imposes a looser bottleneck than respiratory droplet transmission allowing propagation of antiviral resistance. Sci Rep. 2016 Jul;6: 29793.

10 Long AM, Short SM. Seasonal determinations of algal virus decay rates reveal overwintering in a temperate freshwater pond. ISME J. 2016 Mar;10(7):1602. 
11 Sundell N, Andersson LM, Brittain-Long R, Lindh M, Westin J. A four year seasonal survey of the relationship between outdoor climate and epidemiology of viral respiratory tract infections in a temperate climate. J Clin Virol. 2016 Nov;84:59-63.

12 Tadjbakhsh H. Traditional methods used for controlling animal diseases in Iran. Rev Sci Tech. 1994 Jun;13(2):599-614.

13 Tadjbakhsh H. A survey of the views of Iranian savants (especially Persian Muslim physicians) on the subject of contagious diseases and immunity. Med J Islam Repub Iran MJIRI. 1990 Nov;4(4):273-86.

14 Moattar F, Shams Ardekani MR, Ghannadi A. The life of Jorjani: one of the Persian pioneers of medical encyclopedia compiling: on the occasion of his 1000th birthday anniversary (434, A.H. - 1434, A.H.). Iran Red Crescent Med J. 2013 Sep;15(9):763-6.

15 Clendening L. Source book of medical history. Courier Corporation; 1960.

16 Cavanaugh R. Dr Girolamo Fracastoro (1478-1553) and the poetry of Syphilis. J Med Biogr. 2017 Feb;25(1):60-1.

17 Nutton V. The reception of Fracastoro's theory of contagion: the seed that fell among thorns? Osiris. 1990;6:196-234.

18 Karamanou M, Panayiotakopoulos G, Tsoucalas G, Kousoulis AA, Androutsos G. From miasmas to germs: a historical approach to theories of infectious disease transmission. Infez Med. 2012 Mar;20(1):58-62.

19 Ranlet P. The British, the Indians, and smallpox: what actually happened at Fort Pitt in 1763? Pa Hist. 2000 Jul;67(3):427-41.

20 Pasteur L. Mémoire sur les corpuscules organisés qui existent dans l'atmosphère. Paris: impr. de C. Lahure, DL 1862, available from http: //catalogue.bnf.fr/ark: /12148/ cb31065549p. 1861

21 Flügge C. Ueber luftinfection. Z Hyg. 1897 Feb;25(1):179-224.

22 Chamberland C. Chimie physiologique: Sur un filtre donant de l'eau physiologiquement pure. Comptes Rendus des Sciences de l'Académie des Sciences. Available from: https://gallica.bnf.fr/ark:/12148/bpt6k3055h. (Paris); 1884. p. 247.

23 Bos L. Beijerinck's work on tobacco mosaic virus: historical context and legacy. Philos Trans R Soc B Biol Sci. 1999 Mar;354(1383): 675-85.

24 Loeffler F, Frosch P. Berichte der Kommission zur Erforschung der Maul- und Klauenseuche bei dem Institut für Infektionskrankheiten in Berlin. Zentralblatt für Bakteriologie, Parasitenkunde und Infektionskrankheiten; 1898. p. 371-91.

25 Simon CE. The filterable viruses. Physiol Rev. 1923 Oct;3(4):483-508.

26 Dujarric de la Rivière R. La grippe est-elle une maladie à virus filtrant? Comptes rendus de l'académie des sciences. 1918. p. 606-7.

27 Nicolle C, Lebailly C. Quelques notions expérimentales sur le virus de la grippe. Comptes rendus de l'académie des sciences. 1918.
28 Shope RE. Swine influenza III. Filtration experiments and etiology. J Exp Med. 1931 Jul; 54(3):373-85.

29 Achievements in public health, 1900-1999: control of infectious diseases [Internet]. [cited 2016 Apr 13]. Available from: http://www. cdc.gov/mmwr/preview/mmwrhtml/ mm4829a1.htm.

30 Armstrong GL, Conn LA, Pinner RW. Trends in infectious disease mortality in the United States during the 20th century. JAMA. 1999 Jan;281(1):61-6.

31 Reid AH, Taubenberger JK, Fanning TG. Evidence of an absence: the genetic origins of the 1918 pandemic influenza virus. Nat Rev Microbiol. 2004 Nov;2(11):909-14.

32 Elgin WF. Influence of temperature on vaccine virus. Public Health Pap Rep. 1900;26: 80-3.

33 Flexner S, Lewis PA. Experimental epidemic poliomyelitis in monkeys. J Exp Med. 1910 Mar;12(2):227-55.

34 Flexner S, Amoss HL. Diffusion and survival of the poliomyelitic virus. J Exp Med. 1915; 21(5):509-14.

35 Chapin CV, Charles V. The sources and modes of infection. New York: J. Wiley; 1910.

36 Wells WF. On air-borne infection. Study II. Droplets and droplet nuclei. Am J Epidemiol. 1934.

37 Wells WF. Apparatus for the study of the bacterial behaviour of air. Am J Public Health Nations Health. 1933 Jan;23(1):58-9.

38 Wells WF, Brown HW. Recovery of influenza virus suspended in air and its destruction by ultraviolet radiation1. Am J Epidemiol. 1936; 24(2):407-13

39 Lewis PA, Shope RE. Swine influenza II. A hemophilic bacillus from the respiratory tract of infected swine. J Exp Med. 1931 Jul;54(3): 361-71.

40 Wells WF, Wells MW, Wilder TS. The environmental control of epidemic contagion I. an epidemiologic study of radiant disinfection of air in day schools. Am J Epidemiol. 1942 Jan;35(1):97-121.

41 Mundo FDD, Mc Khann CF. Effect of ultraviolet irradiation of air on incidence of infections in an infants' hospital. Am J Dis Child. 1941 Feb;61(2):213-25.

42 Coleman KK, Sigler WV. Airborne influenza a virus exposure in an elementary school. Sci Rep. 2020 Feb;10(1):1859.

43 Wells WF. An apparatus for the study of experimental air-borne disease. Science. 1940 Feb;91(2355):172-4.

44 Edward DGFF, Lush D, Bourdillon RB. Studies on air-borne virus infections II. The killing of virus aerosols by ultra-violet radiation. J Hyg. 1943 Jan;43(1):11-5.

45 Loosli CG, Lemon HM, Robertson OH, Appel E. Experimental air-borne influenza infection. I. Influence of humidity on survival of virus in air. J Hyg. 1943;43(1):205-6.
46 Robertson $\mathrm{OH}$, Puck TT, Wise H. The construction and operation of experimental rooms for the study of air-borne infection. J Exp Med. 1946 Dec;84(6):559-67.

47 Lester W. The influence of relative humidity on the infectivity of air-borne influenza a virus (PR8 strain). J Exp Med. 1948 Sep;88(3): 361-8.

48 Mitchell CA, Guerin LF, Robillard J. Decay of influenza a viruses of human and avian origin. Can J Comp Med. 1968 Oct;32(4):544-6.

49 Goldberg LJ, Watkins HM, Boerke EE, Chatigny MA. The use of a rotating drum for the study of aerosols over extended periods of time. Am J Hyg. 1958 Jul;68(1):85-93.

50 Edward DGFF. Resistance of influenza virus to drying and its demonstration on dust. Lancet. 1941 Nov;238(6170):664-6.

51 Bean B, Moore BM, Sterner B, Peterson LR Gerding DN, Balfour HH. Survival of influenza viruses on environmental surfaces. J Infect Dis. 1982 Jan;146(1):47-51.

52 Ikeda K, Tsujimoto K, Suzuki Y, Koyama AH. Survival of influenza A virus on contaminated student clothing. Exp Ther Med. 2015 Apr; 9(4):1205-8.

53 Kling C, Petterson A, Wernstedt W. Experimental and pathological investigation. I. The presence of the microbe of infantile paralysis in human beings. Commun Inst Med Etat Stockh. 1912;35.

54 Horstmann DM. The poliomyelitis story: a scientific hegira. Yale J Biol Med. 1985;58(2): 79-90.

55 Rhodes AJ, Clark EM, Knowles DS, Goodfellow AM, Donohue WL. Prolonged survival of human poliomyelitis virus in experimentally infected river water. Can J Public Health. 1950 Apr;41(4):146-9.

56 Maxcy KF, Howe HA, Ridenour GM, Miller HE. The significance of the finding of the virus of infantile paralysis in sewage. Sew Works J. 1943;15(6):1101-14.

57 Chang SL. Water borne viral infections and their prevention. Bull World Health Organ. 1968;38(3):401-14.

58 Maxcy KF. Hypothetical relationship of water supplies to poliomyelitis. Am J Public Health. 1943 Jan;33(1):41-5.

59 Kramer SD, Gilliam AG, Molner JG. Recovery of the virus of poliomyelitis from the stools of healthy contacts in an institutional outbreak. Public Health Rep. 1939 Oct; 54(43):1914-22.

60 Trask JD, Paul JR. Observations on fecal examinations in poliomyelitis. Am J Public Health Nations Health. 1941 Mar;31(3):23944.

61 Lensen SG, Rhian M, Stebbins MR, Backus $\mathrm{RC}$, Peterson CE. Inactivation of partially purified poliomyelitis virus in water by chlorination: III. Experiments with natural waters. Am J Public Health Nations Health. 1949 Sep; 39(9):1120-8.
History of Discoveries on Virus

Persistence in the Environment 
62 Paul JR, Trask JD. Occurrence and recovery of the virus of infantile paralysis from sewage. Am J Public Health Nations Health. 1942 Mar;32(3):235-9.

63 Neefe JR, Stokes J. An epidemic of infectious hepatitis apparently due to a water borne agent: epidemiologic observations and transmission experiments in human volunteers. J Am Med Assoc. 1945 Aug;128(15):1063-75.

64 Sabin AB, Ward R. The natural history of human poliomyelitis: I. Distribution of virus in nervous and non-nervous tissues. J Exp Med. 1941 May;73(6):771-93.

65 Knight CA. The stability of influenza virus in the presence of salts. J Exp Med. 1944 Mar; 79(3):285-90.

66 Keswick BH, Gerba CP. Viruses in groundwater. Environ Sci Technol. 1980 Nov;14(11): $1290-7$.

67 Neefe JR, Baty JB, Reinhold JG, Stokes J. Inactivation of the virus of infectious hepatitis in drinking water. Am J Public Health Nations Health. 1947 Apr;37(4):365-72.

68 Berg G. Viral pollution of the environment. CRC Press; 1983.

69 Gerba CP, Wallis C, Melnick JL. Viruses in water: the problem, some solutions. Environ Sci Technol. 1975;9(13):1122-5.

70 Bitton G, Fraxedas R, Gifford G. Effect of solar radiation on poliovirus: preliminary experiments. Water Res. 1979 Jan;13(3):225-8.

71 Ward RL, Ashley CS. Effects of wastewater sludge and its detergents on the stability of rotavirus. Appl Environ Microbiol. 1980 Jun; 39(6):1154-8.

72 Lo S, Gilbert J, Hetrick F. Stability of human enteroviruses in estuarine and marine waters. Appl Environ Microbiol. 1976 Aug;32(2): 245-9.

73 Dimmock NJ. Differences between the thermal inactivation of picornaviruses at "high" and "low" temperatures. Virology. 1967 Feb; 31(2):338-53.

74 Pinon A, Vialette M. Survival of viruses in water. Intervirology. 2018;61(5):214-22.

75 Doggett JE, Bynoe ML, Tyrrell DA. Some attempts to produce an experimental vaccine with rhinoviruses. Br Med J. 1963 Jan;1(5322): 34-6.

$76 \mathrm{Chu}$ CM. Inactivation of haemagglutinin and infectivity of influenza and Newcastle disease viruses by heat and by formalin. J Hyg. 1948 Sep;46(3):247-51.

77 Gordon MP, Huff JW, Holland JJ. Heat inactivation of the infectious ribonucleic acids of polio and tobacco mosaic viruses. Virology. 1963 Mar; 19:416-8.

78 Thomas Y, Vogel G, Wunderli W, Suter P, Witschi M, Koch D, et al. Survival of influenza virus on Banknotes. Appl Environ Microbiol. 2008 May;74(10):3002-7.

79 Hirose R, Nakaya T, Naito Y, Daidoji T, Watanabe $\mathrm{Y}$, Yasuda H, et al. Viscosity is an important factor of resistance to alcoholbased disinfectants by pathogens present in mucus. Sci Rep. 2017 Oct;7(1):13186.
80 Labadie T, Batéjat C, Manuguerra JC, Leclercq I. Influenza virus segment composition influences viral stability in the environment. Front Microbiol. 2018;9:1496.

81 Reed ML, Bridges OA, Seiler P, Kim JK, Yen $\mathrm{HL}$, Salomon $\mathrm{R}$, et al. The $\mathrm{pH}$ of activation of the hemagglutinin protein regulates $\mathrm{H} 5 \mathrm{~N} 1$ influenza virus pathogenicity and transmissibility in ducks. J Virol. 2010 Feb;84(3):152735.

82 Shigematsu S, Dublineau A, Sawoo O, Batéjat C, Matsuyama T, Leclercq I, et al. Influenza A virus survival in water is influenced by the origin species of the host cell. Influenza Other Respir Viruses. 2014 Jan;8(1):123-30.

83 Hinshaw VS, Webster RG, Turner B. Waterbone transmission of influenza A viruses? Intervirology. 1979;11(1):66-8.

84 Bitton G, Mitchell R. Effect of colloids on the survival of bacteriophages in seawater. Water Res. 1974;8(4):227-9.

85 Smith EM, Gerba CP, Melnick JL. Role of sediment in the persistence of enteroviruses in the estuarine environment. Appl Environ Microbiol. 1978 Apr;35(4):685-9.

86 LaBelle RL, Gerba CP. Influence of estuarine sediment on virus survival under field conditions. Appl Environ Microbiol. 1980 Apr; 39(4):749-55

87 De Flora S, De Renzi GP, Badolati G. Detection of animal viruses in coastal seawater and sediments. Appl Microbiol. 1975 Sep;30(3): 472-5.

88 Bitton G. Introduction to environmental virology. Wiley-Interscience; 1980.

89 Foster DM, Emerson MA, Buck CE, Douglas S. Ozone inactivation of cell- and fecal-associated viruses and bacteria. Water Pollut Control Fed. 1980;52(8):2174-84.

90 Tifft EC, Moffa PE, Richardson SL, Field RI Enhancement of high-rate disinfection by sequential addition of chlorine and chlorine dioxide. J Water Pollut Control Fed. 1977 Jul; 49(7):1652-8

91 Levaditi C, Kling C, Lépine P. Nouvelles recherches experimentales sur la transmission de la poliomyelite par la voie digestive. Action du chlore sur le virus poliomyelitique. Bull Académie Médecine Paris. 1931;105:190.

92 Trask JD, Melnick JL, Wenner HA. Chlorination of human, monkey-adapted and mouse strains of poliomyelitis virus12. Am J Epidemiol. 1945 Jan;41(1):30-40.

93 Magnusson S, Gundersen K, Brandberg A, Lycke E. Marine bacteria and their possible relation to the virus inactivation capacity of sea water. Acta Pathol Microbiol Scand. 1967 Nov;71(2):274-80.

94 Shuval HI, Thompson A, Fattal B, Cymbalista $S$, Wiener Y. Natural virus inactivation processes in seawater. J Sanit Eng Div. 1971; 97(5):587-600.

95 Tong J, Trapido-Rosenthal H, Wang J, Wang Y, Li QX, Lu Y. Antiviral activities and putative identification of compounds in microbial extracts from the Hawaiian coastal waters. Mar Drugs. 2012 Feb;10(3):521-38.
96 Gundersen K, Brandberg A, Magnusson S Lycke E. Characterization of a marine bacterium associated with virus inactivating $\mathrm{ca}$ pacity. Acta Pathol Microbiol Scand. 1967; 71(2):281-6.

97 Lycke E, Magnusson S, Lund E. Studies on the nature of the virus inactivating capacity of sea water. Arch Gesamte Virusforsch. 1965;17(3):409-13.

98 Magnusson S, Hedström CE, Lycke E. The virus inactivating capacity of sea water. Acta Pathol Microbiol Scand. 1966;66(4):551-9.

99 Rodriguez-Lazaro D, Cook N, Ruggeri FM, Sellwood J, Nasser A, Nascimento MSJ, et al. Virus hazards from food, water and other contaminated environments. Fems Microbiol Rev. 2012 Jul;36(4):786-814.

100 Simmonds P, Adams MJ, Benkő M, Breitbart M, Brister JR, Carstens EB, et al. Consensus statement: virus taxonomy in the age of metagenomics. Nat Rev Microbiol. 2017 Mar;15(3):161.

101 Prussin AJ, Marr LC, Bibby KJ. Challenges of studying viral aerosol metagenomics and communities in comparison with bacterial and fungal aerosols. FEMS Microbiol Lett. 2014 Aug;357(1):1-9.

102 Yang W, Elankumaran S, Marr LC. Concentrations and size distributions of airborne influenza A viruses measured indoors at a health centre, a day-care centre and on aeroplanes. J R Soc Interf. 2011 Aug;8(61):117684.

103 Whon TW, Kim MS, Roh SW, Shin NR, Lee HW, Bae JW. Metagenomic characterization of airborne viral DNA diversity in the near-surface atmosphere. J Virol. 2012 Jan; 86(15):8221-31.

104 Djikeng A, Kuzmickas R, Anderson NG Spiro DJ. Metagenomic analysis of RNA viruses in a fresh water lake. PLoS One. 2009 Sep;4(9):e7264.

105 Munang'andu HM. Environmental viral metagenomics analyses in aquaculture: applications in epidemiology and disease control. Front Microbiol. 2016 Dec;7:1986.

106 Cavicchioli R. Microbial ecology of Antarctic aquatic systems. Nat Rev Microbiol. 2015 Nov;13(11):691-706.

107 Brum JR, Ignacio-Espinoza JC, Roux S, Doulcier G, Acinas SG, Alberti A, et al. Ocean plankton. Patterns and ecological drivers of ocean viral communities. Science. 2015 May;348(6237):1261498.

108 Rusiñol M, Martínez-Puchol S, Timoneda N, Fernández-Cassi X, Pérez-Cataluña $A$, Fernández-Bravo A, et al. Metagenomic analysis of viruses, bacteria and protozoa in irrigation water. Int J Hyg Environ Health. 2020 Mar;224:113440.

109 Hesse U, van Heusden P, Kirby BM, Olonade I, van Zyl LJ, Trindade M. Virome assembly and annotation: a surprise in the $\mathrm{Na}$ mib Desert. Front Microbiol. 2017 Jan;8:13. 
110 Hsu T, Joice R, Vallarino J, Abu-Ali G, Hartmann EM, Shafquat A, et al. Urban transit system microbial communities differ by surface type and interaction with humans and the environment. mSystems. 2016 Jun;1(3): e00018-16.

111 Triadó-Margarit X, Veillette M, Duchaine C, Talbot M, Amato F, Minguillón MC, et al. Bioaerosols in the Barcelona subway system. Indoor Air. 2017;27(3):564-75.

112 Adriaenssens EM, Kramer R, Van Goethem MW, Makhalanyane TP, Hogg I, Cowan DA. Environmental drivers of viral community composition in Antarctic soils identified by viromics. Microbiome. 2017 Jul;5(1): 83 .

113 Gong Z, Liang Y, Wang M, Jiang Y, Yang Q, Xia J, et al. Viral diversity and its relationship with environmental factors at the surface and deep sea of Prydz Bay, Antarctica. Front Microbiol. 2018 Dec;9:2981.

114 Roche B, Drake JM, Brown J, Stallknecht DE, Bedford T, Rohani P. Adaptive evolution and environmental durability jointly structure phylodynamic patterns in avian influenza viruses. PLoS Biol. 2014 Aug;12(8): e1001931.

115 Altan-Bonnet N, Perales C, Domingo E. Extracellular vesicles: vehicles of en bloc viral transmission. Virus Res. 2019 May;265:1439.

116 Chen YH, Du W, Hagemeijer MC, Takvorian PM, Pau C, Cali A, et al. Phosphatidylserine vesicles enable efficient en bloc transmission of enteroviruses. Cell. 2015 Feb;160(4): 619-30.

117 Santiana M, Ghosh S, Ho BA, Rajasekaran V, Du WL, Mutsafi Y, et al. Vesicle-cloaked virus clusters are optimal units for inter-organismal viral transmission. Cell Host Microbe. 2018 Aug;24(2):208-20.e8.

118 Feng Z, Hensley L, McKnight KL, Hu F, Madden V, Ping L, et al. A pathogenic picornavirus acquires an envelope by hijacking cellular membranes. Nature. 2013 Apr; 496(7445):367-71.

119 Leblanc D, Gagné MJ, Poitras É, Brassard J. Persistence of murine norovirus, bovine rotavirus, and hepatitis A virus on stainless steel surfaces, in spring water, and on blueberries. Food Microbiol. 2019 Dec;84: 103257.

120 Qiu Y, Li Q, Lee BE, Ruecker NJ, Neumann NF, Ashbolt NJ, et al. UV inactivation of human infectious viruses at two full-scale wastewater treatment plants in Canada. Water Res. 2018 Dec;147:73-81.

121 Welch D, Buonanno M, Grilj V, Shuryak I, Crickmore C, Bigelow AW, et al. Far-UVC light: a new tool to control the spread of airborne-mediated microbial diseases. Sci Rep. 2018 Feb;8(1):2752.
122 Nishisaka-Nonaka R, Mawatari K, Yamamoto T, Kojima M, Shimohata T, Uebanso $\mathrm{T}$, et al. Irradiation by ultraviolet light-emitting diodes inactivates influenza a viruses by inhibiting replication and transcription of viral RNA in host cells. J Photochem Photobiol B. 2018 Dec;189:193-200.

123 Dublineau A, Batéjat C, Pinon A, Burguière AM, Leclercq I, Manuguerra JC. Persistence of the 2009 pandemic influenza A (H1N1) virus in water and on non-porous surface. PLoS One. 2011 Nov;6(11):e28043.

124 Choi S-Y, Cho B. Extermination of influenza virus $\mathrm{H} 1 \mathrm{~N} 1$ by a new visible-light-induced photocatalyst under fluorescent light. Virus Res. 2018 Mar 15;248:71-3.

125 Sonthipet S, Ruenphet S, Takehara K. Bactericidal and virucidal efficacies of potassium monopersulfate and its application for inactivating avian influenza virus on virusspiked clothes. J Vet Med Sci. 2018 Feb; 80(4):568-73.

126 Casanova LM, Jeon S, Rutala WA, Weber DJ, Sobsey MD. Effects of air temperature and relative humidity on coronavirus survival on surfaces. Appl Environ Microbiol. 2010 May;76(9):2712-7.

127 Chan KH, Peiris JS, Lam SY, Poon LL, Yuen KY, Seto WH. The effects of temperature and relative humidity on the viability of the SARS coronavirus. Adv Virol. 2011;2011: 734690.

128 Xiao S, Li Y, Wong TW, Hui DSC. Role of fomites in SARS transmission during the largest hospital outbreak in Hong Kong. PLoS One. 2017 Jul;12(7):e0181558.

129 Pyankov OV, Bodnev SA, Pyankova OG, Agranovski IE. Survival of aerosolized coronavirus in the ambient air. J Aerosol Sci. 2018 Jan;115:158-63.

130 Doremalen N, Bushmaker T, Morris DH, Holbrook MG, Gamble A, Williamson BN, et al. Aerosol and Surface Stability of SARSCoV-2 as Compared with SARS-CoV-1. N Engl J Med. 2020 Apr;382(16):1564-7.

131 Kampf G, Todt D, Pfaender S, Steinmann E. Persistence of coronaviruses on inanimate surfaces and their inactivation with biocidal agents. J Hosp Infect. 2020 Mar;104(3):24651.

132 Morawska L, Milton DK. It is time to address airborne transmission of COVID-19. Clin Infect Dis. 2020 [Online ahead of print].

133 Piercy TJ, Smither SJ, Steward JA, Eastaugh L, Lever MS. The survival of filoviruses in liquids, on solid substrates and in a dynamic aerosol. J Appl Microbiol. 2010 Nov;109(5): 1531-9.

134 Sagripanti JL, Rom AM, Holland LE. Persistence in darkness of virulent alphaviruses, Ebola virus, and Lassa virus deposited on solid surfaces. Arch Virol. 2010 Sep;155(12): 2035-9.

135 Judson S, Prescott J, Munster V. Understanding Ebola virus transmission. Viruses. 2015 Feb;7(2):511-21.
136 Poliquin PG, Vogt F, Kasztura M, Leung A, Deschambault Y, Van den Bergh R, et al. Environmental contamination and persistence of Ebola virus RNA in an Ebola treatment center. J Infect Dis. 2016 Jun;214(Suppl 3): S145.

137 Prescott J, Bushmaker T, Fischer R, Miazgowicz K, Judson S, Munster VJ. Postmortem stability of Ebola virus. Emerg Infect Dis. 2015 May;21(5):856-9.

138 Atkinson MP, Wein LM. Quantifying the routes of transmission for pandemic influenza. Bull Math Biol. 2008 Apr;70(3):82067.

139 Tamerius JD, Shaman J, Alonso WJ, Alonso WJ, Bloom-Feshbach K, Uejio CK, et al. Environmental predictors of seasonal influenza epidemics across temperate and tropical climates. PLoS Pathog. 2013 Mar;9(3): e1003194.

140 Turgeon N, Hamelin M-È, Verreault D, Lévesque A, Rhéaume C, Carbonneau J, et al. Design and validation with influenza a virus of an aerosol transmission chamber for ferrets. Int J Environ Res Public Health. 2019 Jan;16(4):609.

141 Zhou J, Wei J, Choy KT, Sia SF, Rowlands $\mathrm{DK}, \mathrm{Yu} \mathrm{D}$, et al. Defining the sizes of airborne particles that mediate influenza transmission in ferrets. Proc Natl Acad Sci U S A. 2018 Feb;115(10):E2386

142 Vejerano EP, Marr LC. Physico-chemical characteristics of evaporating respiratory fluid droplets. J R Soc Interface. 2018 Feb; 15(139):20170939.

143 Prussin AJ, Schwake DO, Lin K, Gallagher DL, Buttling L, Marr LC. Survival of the enveloped virus Phi6 in droplets as a function of relative humidity, absolute humidity, and temperature. Appl Environ Microbiol. 2018 May;84(12):e00551-18.

144 Shaman J, Kohn M. Absolute humidity modulates influenza survival, transmission, and seasonality. Proc Natl Acad Sci U S A. 2009 Mar; 106(9):3243-8.

145 Shaman J, Goldstein E, Lipsitch M. Absolute humidity and pandemic versus epidemic influenza. Am J Epidemiol. 2011 Jan;173(2): $127-35$.

146 Lowen AC, Steel J. Roles of humidity and temperature in shaping influenza seasonality. J Virol. 2014 Apr;88(14):7692-5.

147 Marr LC, Tang JW, Van Mullekom J, Lakdawala SS. Mechanistic insights into the effect of humidity on airborne influenza virus survival, transmission and incidence. J R Soc Interface. 2019 Jan;16(150):20180298.

148 Ali ST, Wu P, Cauchemez S, He D, Fang VJ, Cowling BJ, et al. Ambient ozone and influenza transmissibility in Hong Kong. Eur Respir J. 2018 Jan;51(5):1800369.
History of Discoveries on Virus

Persistence in the Environment
Intervirology 2020;63:17-32

DOI: $10.1159 / 000511575$ 
149 Hirose R, Nakaya T, Naito Y, Daidoji T, Watanabe Y, Yasuda H, et al. Mechanism of human influenza virus RNA persistence and virion survival in feces: mucus protects virions from acid and digestive juices. J Infect Dis. 2017 Jul;216(1):105-9.

150 Kormuth KA, Lin K, Prussin AJ, Vejerano $\mathrm{EP}$, Tiwari AJ, Cox SS, et al. Influenza virus infectivity is retained in aerosols and droplets independent of relative humidity. J Infect Dis. 2018 Sep;218(5):739-47.

151 Valleron AJ, Bouvet E, Garnerin P, Ménarès J, Heard I, Letrait S, et al. A computer network for the surveillance of communicable diseases: the French experiment. Am J Public Health. 1986 Nov;76(11):1289-92.
152 Larvor G, Berthomier L, Chabot V, Le Pape B, Pradel B, Perez L. MeteoNet, an open reference weather dataset by Meteo-France [Internet]. 2020.

153 Singanayagam A, Zhou J, Elderfield RA, Frise R, Ashcroft J, Galiano M, et al. Characterising viable virus from air exhaled by H1N1 influenza-infected ferrets reveals the importance of haemagglutinin stability for airborne infectivity. PLoS Pathog. 2020 Feb; 16(2):e1008362.

$154 \mathrm{Hu}$ M, Yang G, DeBeauchamp J, Crumpton JC, Kim H, Li L, et al. HA stabilization promotes replication and transmission of swine H1N1 gamma influenza viruses in ferrets. eLife. 2020 Jun;9:e56236.
155 Lakdawala SS, Lamirande EW, Suguitan AL, Wang W, Santos CP, Vogel L, et al. Eurasian-origin gene segments contribute to the transmissibility, aerosol release, and morphology of the 2009 pandemic H1N1 influenza virus. PLoS Pathog. 2011 Dec;7(12): e1002443.

156 Kormuth KA, Lin K, Qian Z, Myerburg MM, Marr LC, Lakdawala SS. Environmental persistence of influenza viruses is dependent upon virus type and host origin. mSphere. 2019 Aug;4(4):e00552-19. 